Edited by C Lacroix, ETH Zurich, Switzerland

Woodhead Publishing Series in Food Science, Technology and

Nutrition No. 201, ISBN-13: 9781845696696

(C) 2011 Woodhead Publishing Limited

\title{
Applications of protective cultures, bacteriocins and bacteriophages in fresh seafood and seafood products
}

\author{
Marie-France Pilet ${ }^{1} \&$ Françoise Leroi $^{2}$
}

\footnotetext{
${ }^{1}$ UMR INRA 1014 Sécurité des Aliments et Microbiologie, ONIRIS Site de la Géraudière, BP 82225, 44322 NANTES Cedex 03, France

Tel : +33 251785523 ; Fax : +33 2517855 20, email : marie-france.pilet@oniris-nantes.fr

${ }^{2}$ Laboratoire de Science et Technologie de la Biomasse Marine, Ifremer, Rue de l'Ile d'Yeu, BP 21105, 44311 Nantes Cedex 03, France.

Tel: +33 240374172 ; Fax : +33 240374071 ; email: fleroi@ifremer.fr
}

Chapter content :

1 Introduction

2 Microbial risk in seafood

2.1 Microbial seafood-borne disease statistics

2.2 Microbial pathogens in seafood

2.3 Microbial seafood safety risk assessment

3 Lactic acid bacteria in seafood products

3.1 Lactic acid bacteria in living fish

3.2 Lactic acid bacteria in fresh fish stored in ice or under packaging

3.3 Lactic acid bacteria in lightly preserved fish

3.4 Spoilage potential of LAB

4 Bioprotective $L A B$, bacteriocin and bacteriophage for bacteria control

4.1 Control of pathogenic bacteria

4.2 Control of spoiling microorganism

5 Industrial application

6 Future trends 


\begin{abstract}
:
Microbial seafood-borne disease represents 10 to $20 \%$ of the total food-borne outbreaks. Most of them are from bacterial origin and involve seafood products that have been contaminated by pathogenic Vibrio, Listeria monocytogenes and histaminogen bacteria. On the other hand, seafood products are very sensitive to the development of spoiling bacteria producing off-odours. Pathogenic and spoiling microflora are not always reduced or limited by the processing steps that are currently used in these foodstuffs, and the interest for alternative techniques such as bioprotection to improve quality and safety of seafood has increased in the last years. Among the microbial flora of lightly preserved seafood products, lactic acid bacteria usually become dominant during the storage under vacuum or modified atmosphere. In some cases these bacteria are responsible for spoilage but some of them have demonstrated potential for pathogenic or spoiling microflora inhibition. Those bacteria as far as some bacteriocins have been tested, mainly for the control of Listeria monocytogenes in cold smoked salmon and in a lesser extend in other products to enhance sensory shelf-life. Many successful results have been obtained at the laboratory scale, nevertheless, the application in seafood industry is still limited.
\end{abstract}

Keywords: Biopreservation of seafood, seafood safety and spoilage, lactic acid bacteria, sensory quality, Listeria monocytogenes. 


\section{Introduction}

Fishery products contribute to a huge source of valuable nutrients such as proteins, vitamins, minerals, omega-3 fatty acid, taurine etc. However, they are also responsible for human intoxication and infection, and 10 to $20 \%$ of the food-borne illnesses are attributed to fish consumption. Aetiology of seafood is not always known but it is clear that indigenous bacteria present in marine environment as well as the result of post contamination during process are responsible for many cases of illnesses.

In the last years, the traditional processes applied to seafood like salting, smoking and canning have decreased in favour of mild technologies involving lower salt content, lower cooking temperature and vacuum (VP) or modified atmosphere packing (MAP). These products designed as lightly preserved fish products (LPFP) are usually produced from fresh seafood and further processing increases risk of cross contamination. The treatments are usually not sufficient to destroy microorganisms and in some cases psychrotolerant pathogenic and spoiling bacteria can develop during the extended shelf-life of LPFP (usually up to 10 days). As several of these products are eaten raw, minimising the presence and preventing growth of microorganisms is essential for the food quality and safety.

The microbial safety and stability of food are based on an application of preservative factors called hurdles. Most of the decontamination technologies such as the oldest one, cooking, and more recent mild technologies i.e. pulsed-light, high pressure, ozone, ultrasound... are not efficient or not compatible with the delicate texture and flavour of seafood. Chemical preservative have also been used but consumers require more natural products with lower chemical treatment. An alternative solution that is gaining more and more attention is the biopreservation technology (Dortu and Thonart, 2009; Calo-Mata et al., 2008; Rodgers, 2001). It consists in inoculating food with microorganisms, or their metabolites, selected for their antibacterial properties. Lactic acid bacteria (LAB) are generally good candidates as some of them show natural capacities to inhibit growth of microorganisms and because they are naturally present in many food products and eaten for years by human without any safety risk. LAB have complex nutritional requirements and in order to obtain a good implantation, it is generally the strategy to use bacteria isolated from the food that has to be preserved. LAB in fish flesh has long been disregarded because they are not currently present in seafood. However, in some environmental conditions, for instance in lightly processed seafood with salt, smoke, vacuum or modified atmosphere packaging, LAB can become dominant. Their occurrence and role vary according to fish and bacterial species. In some cases, they may be responsible for strong off-flavours and degradation of texture that unable their use as food preservative. In many other cases they do not change the organoleptic characteristics of the products and their use as protective culture could offer an alternative to the use of chemical compounds. However, the knowledge of LAB from seafood is still in its infancy, explaining why their use by human for preservation or transformation of marine products is still limited.

After a description of the microbial risks associated with seafood, this chapter presents the particular position of $L A B$ among the microbial flora of processed seafood and the bioprotective solutions that have so far been proposed to ensure quality and safety of fisheries.

\section{Microbial risk in seafood}

Fish constitutes a major part of protein consumption in many places in the world. In 2006 the total fisheries production, including fish, crustaceans and molluscs, was 143 million tons, about $35 \%$ of which was of aquaculture origin (http://www.fao.org/fishery/statistics/en [accessed 25 January 2010]). Only one hundred and ten million tons were for human consumption, out of this $48 \%$ were marketed as fresh products, $25 \%$ frozen, $15 \%$ canned and $11 \%$ processed (salted, dried, smoked etc.). 


\subsection{Microbial seafood-borne disease statistics}

The number of outbreaks attributed to seafood consumption is generally high $(10-20 \%$ of the total food-borne outbreaks), but varies according to the quality of the surveillance system, the level of consumption (from 5-6 kg in some countries to $180 \mathrm{~kg} / \mathrm{person} / \mathrm{year}$ in Maldives) and the consumers' habits (higher risk associated to raw fish and molluscs consumption). During the period between 1988-1992, the percentage of total number of outbreaks was $7.4 \%$ in the USA (Bean et al., 1996) compared with $21.7 \%$ in Japan during the years 1981-1990 where people consume a larger amount of raw seafood (Lee et al., 1996). Some of the largest food poisoning outbreaks have been associated with seafood. In 1991 in Shanghai, a hepatitis A outbreak due to consumption of clams involved 300000 cases with nine death (Tang et al., 1991). Around at the same time, cholera caused more than 400000 illnesses and more than 4000 deaths in Peru, which primarily source was probably Ceviche, a typical raw lightly marinated fish.

The fish consumption is responsible for higher outbreaks than shellfish (Huss et al., 2000) but the number of cases per outbreak is often much more elevated with shellfish. In finfish, most of the diseases are from bacterial origin, the highest number being attributed to histamine, a biogenic amine from bacterial origin, accounting for $30-40 \%$ of fish intoxication. Histamine fish poisoning is principally due to scombroid fish consumption such as tuna and mackerel which contain high level of histidine, the precursor of histamine, although other species have also been involved (Dalgaard and Emborg, 2008). In molluscs, virus generally account for more than $50 \%$ of outbreaks but the lack of routine sensitive detection methods cannot allow a precise estimation. Vibrio parahaemolyticus, $V$. vulnificus, and $V$. cholerae are also an important cause of illnesses in molluscan bivalves that concentrate different particles during their filter feeding. Of the 2500 reported cases of illnesses due to bivalves mollusc, 50\% were due to Vibrio, with 95 deaths during the period 1984-1993 in US (Wittman and Flick, 1995). As biopreservation is not used at the moment for live molluscs, the chapter will focus on microbial risk in finfish.

\subsection{Microbial pathogens in seafood}

Microbial seafood pathogens can be classified in two categories:

a) Indigenous bacteria that are naturally present in the marine environment i.e. Vibrio vulnificus, V. parahaemolyticus and V. cholerae, Listeria monocytogenes, Clostridium botulinum and Aeromonas hydrophila. The presence of indigenous microorganisms is normally not a safety concern since they are present at too low level to cause disease. Moreover, adequate cooking eliminates those bacteria or their toxin (toxin of $C$. botulinum is thermolabile). Therefore, the hazard concerns i) products in which the growth of those bacteria is possible during the storage period and which are eaten raw or insufficiently cooked. It can be the case for Vibrio in raw fish or tropical shrimp preparation. Vibrio are mesophilic bacteria found in tropical water or in temperate water at the end of summer. Their growth is very rapid if the products are kept some hours at room temperature. $L$. monocytogenes is also a problem in lightly preserved fish products (LPFP) such as coldsmoked, lightly marinated fish or insufficiently cooked seafood stored under VP or MAP. During the extending shelf-life of those products, $L$. monocytogenes can still develop and reach unacceptable concentration. Insufficiently salted seafood stored in anaerobic condition or traditional fermented fish can also support growth of $C$. botulinum and production of the botulinic toxin ii) Scombroid and Clupeid fish kept some hours at abuse temperature $\left(>5^{\circ} \mathrm{C}\right)$ with high histamine content. The origin of histamine producing bacteria is not completely well established although there is evidence that some of them are present in the gut, gills and skin of the fish. Most of the histamine producers are mesophilic bacteria (Morganella morganii, Hafnia alvei, Raoultella planticola) that produce histamine when fish is stored at abuse temperature, for instance during storage on the vessels or during the thawing step 
before processing. More recently, psychrotolerant bacteria (Photobacterium phosphoreum, Morganella psychrotolerans) that grow at $2^{\circ} \mathrm{C}$ have been associated with histamine fish poisoning in cold-smoked tuna (Emborg and Dalgaard, 2006). Once produced, histamine is not destroyed during the canning process and may cause serious problem in those products. All those indigeneous bacteria can also post contaminate products during the processing step, either by cross-contamination in industry or because some of them (L. monocytogenes) are ubiquitous bacteria naturally present in many food industrial environments or in human skin.

b) Exogenous bacteria due to post contamination during fish processing: those bacteria are the same as those that can be found in other food products i.e. Staphylococcus aureus, Salmonella, Shigella, Clostridium perfringens, Bacillus cereus, Yersinia enterocolitica or enterohaemorrhagic Escherichia coli. Some of those bacteria can also be present in costal and estuarine marine water or in aquaculture ponds, due to human activities. They constitute a serious problem since low dose can cause illness. Normal cooking eliminates the risk but a lot of ready-to-eat food are not or insufficiently cooked (shellfish salads, shrimps, soup etc.). Moreover, the toxin of $S$. aureus is heatstable.

The different pathogenic bacteria, symptoms, minimal infectious doses and seafood responsible for infection are summarized by Feldhusen (2000) and Lee and Rangdale (2008).

\subsection{Microbial seafood safety risk assessment}

Different qualitative and quantitative risk assessment strategies have been used to categorize risk from seafood. Risk categories and associated microorganisms are described in Table 1. In a semi quantitative seafood safety risk assessment performed on statistics of seafood-borne illnesses during the period 1990-2000 in Australia, Sumner and Ross (2002) have shown that very high risks were due to $V$. parahaemolyticus and $V$. cholerae in cooked prawns, $V$. vulnificus in oysters, L. monocytogenes in cold-smoked seafoods, enteric bacteria in imported cooked shrimp eaten by vulnerable consumers and scombrotoxicosis. Almost all the hazard/product pairs in this category have caused the outbreaks of food poisoning in Australasia. In developed countries, changing in consumers' habit has led to an increase of ready-to-eat and convenient food, concept that includes both the easy-to-use aspect and an extended shelf-life of the products. The nutritional aspects are also more and more taken into consideration by the consumers who want natural products, with technological treatment and level of preservatives as low as possible. LPFP, like carpaccio-type marinated fish, coldsmoked fish, peeled and lightly cooked shrimp, desalted cod packed under VP or MAP etc., meet those requirements and their production has increased dramatically those last years. The major safety risk associated with LPFP is L. monocytogenes with a prevalence quite elevated, varying from 2 to 60\% depending of the studies (Beaufort et al., 2007; Hu et al., 2006; Gudmundsdöttir et al., 2005; Nakamura et al., 2004; Jorgensen and Huss, 1998; Valdimarsson et al., 1998). L. monocytogenes may be present in raw material in low number but contamination mainly occurs during processing. A strict hygienic manufacturing practice has been emphasised to reduce the cross contamination with $L$. monocytogenes with daily cleaning and disinfection of the production lines and special attention to hygiene of the employees. However, a production of LPFP consistently free of the bacterium seems impossible as $L$. monocytogenes is not destroyed by the different processing steps. The risk associated with consumption of LPFP is due to the possible growth of L. monocytogenes rather than to the initial contamination of freshly processed products, which are commonly inferior to $1 \mathrm{CFU} \mathrm{g}{ }^{-1}$. L. monocytogenes can multiply at low temperatures, in a wide range of $\mathrm{pH}$, in aero and anaerobic conditions in the presence of salt or smoke and it can sometimes overpass the European tolerated limit of $100 \mathrm{CFU} \mathrm{g}^{-1}$ (Commission Regulation 1441/2007/EC). 
In those kind of products with an extended shelf-life, psychrotrophic LAB have time to develop, therefore, their use as protective culture to prevent $L$. monocytogenes and spoiling microorganisms is a subject of increasing investigations.

\section{Lactic acid bacteria in seafood products}

\subsection{Lactic acid bacteria in living fish}

The skin, mucus, gills and gut of fish contain high number of bacteria, whose composition and quantity vary according to the fish species and many environmental parameters. The microbiota of marine fish from temperate waters is usually composed of Gram negative psychrotrophic bacteria from the genera Pseudomonas, Shewanella, Acinetobacter, Aeromonas, Vibrio, Moraxella, Psychrobacter, Photobacterium. Nevertheless, Gram positive such as Micrococcus, Corynebacterium, Bacillus, Lactobacillus and Clostridium may also be present in variable proportions. In tropical fish the microflora has the same composition overall, but with a predominance of Gram positive bacteria, Enterobacteriaceae and Vibrionaceae.

Although not the most common, it is generally accepted that LAB occur among the normal intestinal microbiota of fish from the first few days and towards. Many genera and species have been reported : Lactobacillus plantarum, Carnobacterium maltaromaticum (previously C. piscicola),C. divergens, C. gallinarum and C. inhibens, Streptococcus spp., Leuconostoc spp., Lactococcus lactis and Lc. piscium, Vagococcus salmoninarum, Weissella spp., etc. (Yang et al., 2007; Huber et al., 2004; Ringo et al., 2001; Jöborn et al., 1999; Ringo and Gatesoupe, 1998). LAB are generally recognized as non-pathogenic for human but virulence of some species such as Lactococcus garvieae, C. maltaromaticum and Weissella sp. has been clearly established for farmed fish (Liu et al., 2009; Eldar et al., 1996; Toranzo et al., 1993).

\subsection{Lactic acid bacteria in fresh fish stored in ice or under packaging}

At fish death and during evisceration and filleting, microorganisms may contaminate the flesh and this often occur all along the production line as far as in the finished product. LAB are not naturally dominant in the microbiota of fresh fish stored in ice. The low temperature, high post-mortem $\mathrm{pH}(>6)$, low percentage of sugars (0.2 to $1.5 \%$ depending on the species) and high content of non-protein low molecular weight nitrogenous compounds are more favourable for the Gram negative psychrotrophic bacteria naturally present in living fish, like Pseudomonas and Shewanella. VP does not slow their growth as many of them, notably Shewanella putrefaciens, Photobacterium phosphoreum and the Vibrionaceae, are able to use trimethylamine oxide (OTMA), a common marine molecule, as a terminal electron acceptor in anaerobic respiration. These bacteria produce strong off-odours typical of rotten fish due to the reduction of OTMA to trimethylamine, and also sulphurous odours resulting from the breakdown of cysteine and methionine (Gram and Huss, 1996). MAP decreases the number of respiratory microorganisms like Pseudomonas and Shewanella but $P$. phosphoreum is resistant to $\mathrm{CO}_{2}$. It therefore multiplies quickly in this type of product and is recognized as the main spoilage bacterium of fresh MAP fish (Dalgaard et al., 1997). This explains why this type of packaging only slightly increases the use-by date of fish compared to meat. However numerous studies carried out on fatty or low-fat fish have shown that more LAB are found in products preserved under MAP than under air (Lalitha et al., 2005; Fletcher et al., 2004). MAP selects both $P$. phosphoreum and LAB but the latter are less competitive and so often play a minor role in the spoilage. When $P$. phosphoreum is eliminated by a frozen step, LAB become the dominant group during the MAP storage of thawed fish (Dalgaard et al., 2006; Emborg et al., 2002). 


\subsection{Lactic acid bacteria in lightly preserved fish}

LPFP are often stored at chilled temperature and under VP or MAP to extend shelf-life and are highly perishable. The initial microbiota depends strongly on the hygiene conditions in the company but is often dominated by Gram negative bacteria typical of fresh fish (GonzalezRodriguez et al., 2002; Leroi et al., 1998; Paludan-Müller et al., 1998). During storage, Gram positive bacteria, particularly $L A B$, become predominant, sometimes associated with Enterobacteria and Brochothrix thermosphacta (Jaffrès et al., 2008; Cardinal et al., 2004). $\mathrm{LAB}$ can easily reach $10^{7-8} \mathrm{CFU} \mathrm{\textrm {g } ^ { - 1 }}$ and such amounts have been found in cold-smoked salmon (CSS) (Leroi et al., 2000; Leroi et al., 1998), smoked trout (Lyhs et al., 1998), smoked herring (Gancel et al., 1997), salted lumpfish roe (Basby et al., 1998), cooked coldwater shrimp (Dalgaard et al., 2003) and warm-water shrimp (Jaffrès et al., 2008; Mejlholm et al., 2005).

The cause of LAB predominance in LPFP has not been extensively studied but it is clear that they are well adapted to the conditions prevailing in those products. Most of the LAB strains isolated from LPFP are psychrotrophic, able to catabolize arginine with low glucose concentration and known to grow with up to $8-10 \%$ of salt. VP and MAP are probably other factors promoting $L A B$ development since they are aero-anaerobic bacteria. It has been demonstrated, by challenge tests performed in CSS, that Lactobacillus sakei, $L b$. alimentarius and $L b$. farciminis grew faster than $S$. putrefaciens, $P$. phophoreum, $B$. thermosphacta and S. liquefaciens (Joffraud et al., 2006).

\subsection{Spoilage potential of LAB}

The use of $L A B$ as protective culture in seafood implies that they do not have any spoiling capacity. LAB have often been thought to play a minor role in the spoilage of marine products. They are not very competitive in refrigerated fresh fish and they produce fewer unpleasant odours compared to Gram negative bacteria like S. putrefaciens, $P$. phosphoreum and Pseudomonas sp. (Leisner, 1992). Although dominant in LPFP, their role is not very clear. Several authors have found no correlation between LAB and sensory spoilage (Leroi et al., 2001; Hildebrandt and Erol, 1988). However, Paludan-Müller et al. (1998) succeeded in increasing the shelf-life of CSS by inhibiting LAB with nisin, suggesting a possible spoiling effect of this bacterial group (for a review of the different characteristics of spoilage, the compounds responsible and their associated precursors, see Huss et al., 1995).

Stohr et al. (2001) clearly showed that some Lactobacillus species found in CSS were very spoiling ( $L b$. sakei) while others had no effect ( $L b$. alimentarius). Lb. sakei generally produces sulphurous and acidic odours (Stohr et al., 2001; Nilsson et al., 1999), associated with the production of $\mathrm{H}_{2} \mathrm{~S}$, acetic acid and ethyl and $n$-propyl acetate (Joffraud et al., 2001), but some $L b$. sakei strains do not affect the organoleptic quality of this product (Weiss and Hammes, 2006). Lb. alimentarius which does not spoil CSS has been identified as the bacterium responsible for the sensory deterioration of marinated herring (Lyhs et al., 2001). Carnobacteria are microorganisms resistant to freezing that grow very well at refrigerated temperatures, in all packaging conditions and in the presence of many preservatives (Laursen et al., 2005; Leroi et al., 2000), explaining why this genus is very often found in refrigerated meat or fish products. The role of this genus is still under discussion (Leisner et al., 2007; Laursen et al., 2005). Many studies show that the inoculation of CSS by various strains of $C$. maltaromaticum and $C$. divergens leads to few or no changes in organoleptic quality (Brillet et al., 2005; Nilsson et al., 1999). When the carnobacteria reach a high enough level, flavours of butter and plastic may be detected, associated with the production of 2,3butanedione (diacetyl) and 2,3-pentanedione (Joffraud et al., 2001; Stohr et al., 2001) but are not sufficient for a trained panel to reject the product (Brillet et al., 2005). In contrast, strains of C. maltaromaticum and C. divergens inoculated into Arctic shrimp generated strong chlorine, malt, nuts and sour odours and the samples were judged unfit for consumption 
(Laursen et al., 2006). Ammonia and numerous alcohols, aldehydes and ketones were produced. Nevertheless, here again, there was variability depending on the strain.

The interaction with other microorganisms should not be disregarded. In a sterile CSS model, Joffraud et al. (2006) have shown that the spoilage observed with $L b$. sakei was weakened in the presence of $S$. liquefaciens even though the latter had also a spoiling effect in monoculture. On the other hand, some associations appear to be much more spoiling than in pure culture (Carnobacterium with Vibrio or $B$. thermosphacta) due to de novo synthesis of total volatile basic nitrogen (Brillet et al., 2005). Similarly, Laursen et al. (2006) showed that the unpleasant odours generated in cooked shrimp by an association of Carnobacterium sp. and $B$. thermosphacta were different from those due to these two bacteria in pure culture.

\section{Bioprotective LAB, bacteriocins and bacteriophages for bacteria control}

The application of protective flora, bacteriophages or bacteriocins on seafood products for biopreservation is generally less documented than in dairy or meat product. The main reason is probably that the early stages of biopreservation have occurred mainly in fermented foodstuffs that are not so developed among seafood products. Moreover, the selection of potential protective bacteria in seafood products remains a challenge since they must be adapted to the seafood matrix (poor in sugar) and their metabolic activities should not change the initial characteristic of the product i.e. by acidification and not induce spoilage that could lead to a sensory rejection.

Among the microbial flora identified in fresh or processed seafood, LAB remains the category that offers the higher potential for direct application as bioprotective culture or for bacteriocin production. Most of the studies concern LPFP such as CSS and focus on the inhibition of $L$. monocytogenes (Table 2), considered as explained before as the main bacterial risk associated with the consumption of these products. The increase of knowledge about the microbial spoilage flora of those foodstuffs has also recently highlighted the new interest of bioprotective culture or biopreservatives to extend the sensory shelf-life of several LPFP.

\subsection{Control of pathogenic bacteria}

Many studies concerning pathogenic bacteria inhibition have been performed in liquid model medium, but the effects are not often confirmed in real products. In the following part of this chapter, we will focus on studies that have given successful results on seafood products.

Control with protective cultures

Among the LAB that were described before, strains belonging to the genus Carnobacterium have been particularly studied for their role as protective flora in CSS, probably because they are not acidic bacteria. They belong to the major lactic acid flora of such products at the end of storage and although their presence can sometimes be associated with spoilage activities on seafood products, in many cases they are not directly responsible for undesirable odours or flavours. Moreover, several Carnobacterium strains are known to produce anti-listerial bacteriocins (Drider et al., 2006).

Two strains of $C$. maltaromaticum isolated from CSS were evaluated for the inhibition of $L$. monocytogenes in VP CSS. Both strains demonstrated their efficiency to limit the growth of this pathogenic bacteria during 31 days of storage at $5^{\circ} \mathrm{C}$ (Nilsson, 1999). The growth of the protective Carnobacterium strains did not modify the sensory characteristic of the product. One of these strains showing the strongest inhibition activity produces a bacteriocin, named carnobacteriocin B2 that was involved in the anti-listerial activity (Nilsson et al., 2004). Three other strains of bacteriocin producing Carnobacterium have been tested with the agar 
diffusion test method against a wide collection of $L$. monocytogenes (51 strains) isolated from seafood. All of the Listeria strains were sensitive. The inhibition was confirmed in co-culture with a mix of L. monocytogenes strains in sterile CSS (Brillet et al., 2004). One of these strains, $C$. divergens V41 showed its ability to maintain $L$. monocytogenes at the initial inoculating level of $20 \mathrm{CFU} \mathrm{g}{ }^{-1}$ during 28 days of storage at $4^{\circ} \mathrm{C}$ and $8^{\circ} \mathrm{C}$. The effect of this strain on sensory characteristics and physico-chemical parameters revealed that it did not spoiled the product (Brillet et al., 2005). In that case also, the inhibitory activity could be linked to the bacteriocin divercin V41, since a bacteriocin negative mutant failed to limit the growth of $L$. monocytogenes in the same conditions (Richard et al., 2003). In the presence of the bacteriocinogenic strain C. maltaromaticum CS526 isolated from surimi, the population

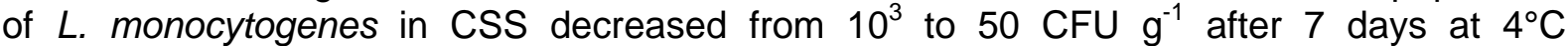
(Yamazaki et al., 2003). This activity could be linked to the production of the bacteriocin piscicocin CS526, since a non-bacteriocin producing strain had a lower effect on the growth of the pathogenic bacteria (Yamazaki et al., 2005; Yamazaki et al., 2003). In another study, the application of $C$. divergens M35 towards L. monocytogenes in CSS resulted in a maximal decrease of $3.1 \log \mathrm{CFU} / \mathrm{g}$ of the pathogenic bacteria after 21 days of storage at $4^{\circ} \mathrm{C}$ whereas a non-bacteriocinogenic strain had no effect (Tahiri et al. 2009).

Among the other $L A B, L b$. sakei has been also used as protective culture for $L$. monocytogenes inhibition on CSS. The strain Lb790 producing sakacin P was compared to a non bacteriocinogenic strain for the inhibition of $L$. monocytogenes. In both cases, no bactericidal effect was obtained but the growth of the pathogenic bacteria was stopped during 28 days at $10^{\circ} \mathrm{C}$ (Katla et al., 2001). Another bacteriocinogenic strain of Lb. sakei isolated from CSS allowed a 4 log reduction of Listeria innocua after 14 days of storage at $4^{\circ} \mathrm{C}$. A reduction of $2 \mathrm{log}$ units after $24 \mathrm{~h}$ at $5^{\circ} \mathrm{C}$ was also demonstrated with that strain in CSS juice towards L. monocytogenes (Weiss and Hammes, 2006).

Mix of bacteriocin-producing $L A B$ like $L b$. casei , $L b$. plantarum and $C$. maltaromaticum were successfully used to limit the growth of L. innocua in CSS (Vescovo et al., 2006). In their study Tomé et al. (2008) have also selected a strain of Enterococcus faecium among five bacteriocinogenic LAB strains for its ability to induce a decrease of the population of $L$. innocua inoculated in CSS. However in these studies the inhibition activities were not confirmed on L. monocytogenes .

Protective cultures have not been applied in many other seafood products except for CSS and L. monocytogenes control. Matamoros et al. (2009a) have performed challenge-tests in cooked shrimp stored under VP using protective $L A B$ and $L$. monocytogenes and $S$. aureus as target pathogens. Two LAB strains, Lactococcus piscium EU2241 and Leuconostoc gelidum EU2247 were efficient to limit the growth of both pathogenic bacteria from 2 to 3 log CFU $g^{-1}$ units after 4 weeks at $8^{\circ} \mathrm{C}$ followed by 1 week at $20^{\circ} \mathrm{C}$. The strain of Leuconostoc produced a bacteriocin-like compound but its activity was slight lower than the Lactococcus strain that was non-bacteriocinogenic.

\section{Control with bacteriocins}

Most of the applications of protective LAB for the control of pathogens have been conducted with bacteriocinogenic strains isolated from seafood products. Some of these bacteriocins have been purified and characterized, in particular those produced by carnobacteria. They are listed in Table 3. Divercin V41 is produced by C. divergens V41 (Métivier et al., 1998) and piscicocin $\mathrm{V} 1 \mathrm{a}$ and $\mathrm{V} 1 \mathrm{~b}$ are two bacteriocins produced by the same strain, $C$. maltaromaticum V1 (Bhugaloo-Vial et al., 1996). Divercin V41 is closed to divergicin M35, another class Ila bacteriocin that is produced by a $C$. divergens strain isolated from frozen smoked mussels (Tahiri et al., 2004).

Piscicocin $\mathrm{V} 1 \mathrm{a}$, piscicocin $\mathrm{V} 1 \mathrm{~b}$ and the bacteriocin produced by $\mathrm{C}$. maltaromaticum $\mathrm{A} 9 \mathrm{~b}$ (Nilsson et al., 2004) are peptides that have been also characterized from other $C$. maltaromaticum strains isolated from meat or cheese (Leisner et al., 2007). All these bacteriocins belong to the class Ila of antilisterial bacteriocins that are heat stable peptides 
with low molecular weight ( $<10 \mathrm{KDa}$ ) (Drider et al., 2006). Piscicocin CS526 produced by C. maltaromaticum CS526 isolated from surimi is also considered as a class Ila bacteriocin although it possesses an alternate residue in the $\mathrm{N}$-terminal consensus motif shared by these peptides (Yamazaki et al., 2005). Carnocin UI49 is the only class I bacteriocin that have been characterized from LAB isolated from seafood products (Stoffels et al., 1992).

Recently, Pinto et al. (2009) have described two bacteriocins produced by strains of Enterococcus faecium and Pediococcus pentosaceus isolated from non fermented shellfish. These peptides were similar to the well-known class II bacteriocins enterocin B and pediocin PA-1.

These last studies suggest that the specificity of bacteriocins is not linked to LAB origin but more likely connected to the bacterial species. A new peptide showing no similarity with other known bacteriocins has been lately characterized. It is called Weissellicin 110 , produced by a strain of Weissella cibaria that is coming from a traditional fermented fish product from Thailand, however its amino acid sequence was not totally determined yet (Srionnual et al., 2007).

Among the peptides that have been described above, very few have been applied directly on seafood products for pathogenic bacteria control. Since bacteriocin purification techniques allowing the recovery of high amounts of peptides in water or salt solution are usually not available, most of the studies use bacteriocin containing supernatant or semi-purified fractions. Crude extract of culture supernatant containing piscicocins or divercin V41 were added on CSS to limit the growth of $L$. monocytogenes during 21 days of storage at $4^{\circ} \mathrm{C}$ and $8^{\circ} \mathrm{C}$ (Duffes et al., 1999). In both cases, the bacteriocins showed a rapid bactericidal effect after 3 days and during the first week of storage. However this effect tended to disappear after 10 days on the opposite with the constant bacteriostatic effect obtained with the protective strain. (Nilsson et al., 1999) made the same observations with semi-purified carnobacteriocin A9b in CSS inoculated with L. monocytogenes. Recently, Tahiri et al. (2009) have also shown that the application of non-purified or purified divergicin M35 on CSS inoculated with $L$. monocytogenes resulted in more rapid but less pronounced reduction of the pathogenic bacteria counts comparing to the producing strain. In the case of $L b$. sakei Lb790, addition of nearly pure sakacin $\mathrm{P}$ to the protective culture carried out an immediate bactericidal effect with no re-growth of the pathogenic bacteria during storage, leading to a more efficient effect than with the protective culture alone (Katla et al., 2001).

Some attempts with commercial bacteriocins like nisin were made to limit the development of L. monocytogenes in CSS (Nilsson et al., 1997). However the growth was only delayed and the final population was similar to that obtained in the control at the end of the storage. In the same way, the results obtained with nisin or pediocin ACCEL to control the growth of $L$. monocytogenes on cooked fish showed a limited and short effect (Yin et al., 2007). It is likely that high and buffered $\mathrm{pH}$ usually encountered in fish products is not suitable for nisin solubility and activity.

\section{Control with bacteriophages}

Although bacteriophages were proposed for several applications in food safety to control the major pathogenic bacteria (Garcia et al., 2008) the only application in seafood is reported by Guenther et al. (2009) in smoked salmon and mixed seafood contaminated with two different L. monocytogenes strains at a level of $10^{3} \mathrm{CFU} \mathrm{^{-1 }}$. The best results were an inhibition by 2 log CFU $g^{-1}$ during 6 days of storage in mixed seafood but this effect was variable considering the product and the L. monocytogenes strain used (Guenther et al., 2009).

\subsection{Control of spoiling microorganism}

Control with protective culture 
Less information is available in this field since the microflora involved in the spoilage activity of seafood product is complex and in most of the cases has not been characterized. The activity of protective culture or bacteriocin is thus directed on the increase of sensory shelflife, or the inhibition of common microbial indicators such as total viable count or LAB.

The Carnobacterium species that were described above for the inhibition of $L$. monocytogenes do not seem to offer a great potential in extending the shelf-life of seafood products. Leroi et al. (1996) succeeded in increasing the sensory use-by-date of CSS slices by inoculating them with strains of Carnobacterium sp. However the results varied depending on the batch treated. For Brillet et al. (2004) no effect of $C$. divergens V41 was recorded on the spoilage flora of CSS and this strain did not improve its organoleptic properties. Using a strain of C. maltaromaticum Paludan-Müller et al. (1998) only slightly extended the shelf-life of smoked salmon. The application of the protective strain C. divergens M35 had no significant effects on the total flora of CSS during storage at $4^{\circ} \mathrm{C}$ for 21 days (Tahiri et al., 2009). Similarly, C. maltaromaticum had no effect on the inhibition of the Gram positive spoilage bacteria $B$. thermosphacta in cooked shrimps (Laursen et al., 2006).

These studies suggest that selection of protective strains to improve the sensory quality of seafood products should focus on specific spoilage microorganism's inhibition. This approach was chosen by Matamoros et al. (2009b) who have isolated seven strains from various marine products on the basis of their activity against many spoiling and pathogenic, Gram positive and Gram negative marine bacteria. Among those strains, two Le. gelidum, and two Lc. piscium demonstrated promising effect in delaying the spoilage of tropical shrimp and of VP CSS. A recent study demonstrated that this protective effect could be due to the inhibition of $B$. thermosphacta identified as one of the major spoiler organisms in cooked shrimp stored under MAP (Fall et al., 2010). One of the strain of Lc. piscium was able to limit by $4.1 \log$ CFU g ${ }^{-1}$ the growth of this target bacteria and thus to avoid the apparition of undesirable odours in the products. Altieri et al. (2005) also succeeded in inhibiting Pseudomonas sp. and $P$. phosphoreum in VP fresh plaice fillets at low temperatures with a strain of Bifidobacterium bifidum.

In the same field, some attempts have been made to select microorganisms that are able to limit the growth of histaminogen microflora or to induce biogenic amines degradations. In seafood, biogenic amines are usually produced by spoiling microorganisms like $P$. phosphoreum or enterobacteria like Morganella morganii or M. psychrotolerans (Emborg and Dalgaard, 2006). They are often used as indirect spoilage indicators, signalling the presence of these bacteria and have thus been included in some models proposed to predict the spoilage of marine products (Jorgensen et al., 2000; Veciana-Nogues et al., 1997). Moreover, histamine is also responsible for food poisoning often linked to seafood consumption (Emborg and Dalgaard, 2006). The studies concerning biogenic amine degrading bacteria mainly focus on fermented fish. A strain of Staphylococcus xylosus showed its ability to degrade histamine and tyramine in salted and fermented anchovy (Mah and Hwang, 2009). In the same way, mixed starter cultures of $L b$. plantarum, $L b$. casei, Pediococcus pentosaceus and S. xylosus were efficient to limit accumulation of histamine, tyramine, cadaverine, putrescine and tryptamine in silver carp sausages (Yongjin et al., 2007).

\section{Control with bacteriocins}

As most of the bacteriocins produced by $L A B$ isolated form seafood products are active against Gram positive flora only, their relevance in preventing spoilage activities that are usually linked to various Gram negative and Gram positive flora is limited. The effect of nisin and pediocin ACCEL was observed on total viable counts of fresh fish fillets at $0^{\circ} \mathrm{C}$ and $4^{\circ} \mathrm{C}$ (Yin et al., 2007). The growth of the total flora was slightly delayed when the bacteriocin were present in the samples stored at $0^{\circ} \mathrm{C}$ but the bacterial counts reached the same level than in the non-treated control after 5 days of storage. In brined shrimp stored at $4.5^{\circ} \mathrm{C}$, nisin $\mathrm{Z}$ was more efficient to extend the microbial shelf-life than other tested bacteriocins (Einarsson and 
Lauzon, 1995) however this effect was limited comparing to the use of food additives such as benzoic or sorbic acids that are usually found in such products.

\section{Industrial application}

Unlike meat or dairy products, seafood products are mainly non-fermented. Therefore the addition of bacterial cultures concept, even with protective effects, is new and probably not totally yet accepted by seafood producers, for which the main goal is to avoid bacterial contamination by the use of good hygienic practices. However, in LPFP, the use of protective culture is gradually considered as an alternative to the use of food additives and it is gaining interest in the seafood industry. Industrial starters like SafePro ${ }^{\circledR}$ (CHR Hansen, DK), Bovamine Meat Culture $^{T M}$ (NPC, US), HOLDBAC ${ }^{T M}$ (Danisco, DK) have been developed for $L$. monocytogenes control for the meat industry, but to our knowledge they are not used in seafood products. Some patents claimed the usefulness of LAB for the treatment of food without seafood specification (Nauth and Zheng, 2006; Stiles et al., 2005; Fliss et al., 2004). However one of them mentions the application of protective culture for seafood (Daniel and Lorre, 2001). This starter named LLO is applied in France for extending the shelf-life of cooked shrimp stored under MAP (Meyer, 2005) and has also showed limitation of histamine production in Tuna stored at $5^{\circ} \mathrm{C}$ (http://www.bioceane.com/uk/pdf/ferment histamine.pdf [Accessed 25 January 2010]).

Concerning bacteriophages, the preparation LISTEX ${ }^{\mathrm{TM}}$ P100 was approved by the FDA for all food products (http://www.ebifoodsafety.com/en/news-2007.aspx [Accessed 25 January 2010]) but no studies are available concerning its efficiency in seafood.

\section{Future trends}

The presence of LAB in many processed seafood product is now well established and although some strains are sometimes involved in spoilage, the bioprotective potential of many strains has been highlighted in the last years. The results obtained with protective culture, bacteriocins and bacteriophages for improving safety and quality of seafood products are at this moment in favor of the use of live cultures that seem to be more efficient than bacteriocin during the long storage period on these foodstuffs. Nevertheless some fields as bacteriophages application or control of spoilage flora still have to be more explored in marine products.

Control of pathogenic bacteria has widely focused on L. monocytogenes considered as the main risk in ready-to-eat seafood. However, in these minimally processed products, the new combination of hurdles like low salt content, coupled to MAP can give selective advantages to other pathogenic bacteria like clostridia, vibrio or staphylococci that should also be addressed in biopreservation studies. It is also important to note that most of the studies are done in challenge-test where sometimes only one strain of the pathogenic bacteria is used as target. The applications of protective cultures, bacteriocin or bacteriophages in naturally contaminated products or using mixed strains of target pathogenic microorganisms isolated form seafood should improve the guaranty to reproduce the results in real industrial products. Concerning control of sensory quality, identification of the specific spoilage flora for the different products is required to select appropriate bioprotective solutions. LPFP spoilage is often due to a complex association of Gram positive and negative bacteria that still need to be explored. The use of combination of protective cultures with different antimicrobial spectrum to master both pathogenic and spoiling bacteria is an exciting challenge for the next years.

Although many protective strains have shown their efficiency to control L. monocytogenes in CSS without any sensory modification, industrial applications delay developing. A brake on 
expansion is that CSS is a traditional product that benefit from a high quality image by the consumers, so producers are not yet ready to communicate on other ingredient than salt and smokewood.

Moreover, the European regulation concerning addition of protective cultures in unfermented ready-to-eat food is still under discussion. In 2007, the European Food Safety Authority (EFSA) adopted guidelines for Qualified Presumption of Safety (QPS) that can be referred to as the European equivalent of the American GRAS status in terms of risk assessment (EFSA, 2007). Any microorganisms used in the food chain should be suitable for the QPS status. A list of 47 LAB species has been published in the EFSA journal (EFSA, 2008). LAB species that gave promissing results in seafood are not included in this list, which is supposed to be annually updated. Proof of their beneficial effect, precise taxonomic data and strong evidence of safety are needed for obtaining the QPS status if notified to EFSA. However, with the increasing market of LPFP, the request for alternative preservation solution and the intensification of research, there is no doubt that biopreservation of fisheries products will expand in the future.

Additional research work is therefore needed in the selection of appropriate strain and their combination to limit the growth of both pathogenic and spoilage flora, understanding of the inhibition mechanism to optimise their activity in the products and characterization and safety aspects of the cultures or their metabolites to obtain the QPS status.

\section{Source of further information and advice}

Borresen, T. (Ed.) 2008. Improving seafood products for the consumer. Cambridge, Woodhead publishing limited.

Informations on QPS status :

http://www.efsa.europa.eu/EFSA/efsa locale-1178620753812 1178620763335.htm

[Accessed 25 January 2010]

Informations on French application of protective culture for seafood products :

http://www.bioceane.com/uk/index.htm

\section{References}

Altieri C, Speranza B, Del Nobile M A and Sinigaglia M (2005), 'Suitability of bifidobacteria and thymol as biopreservatives in extending the shelf life of fresh packed plaice fillets', $\mathrm{J}$ Appl Microbiol, 99, 1294-1302.

Basby M, Jeppesen V F and Huss H H (1998), 'Characterisation of the microflora of lightly salted lumfish (Cyclopterus lumpus) roe stored at $5^{\circ} \mathrm{C}$ ', J Aquat Food Prod Technol, 7, 35-51. Bean N H, Goulding J S, Lao C and Angulo F J (1996), 'Surveillance for foodborne-disease outbreaks-United States, 1988-1992', Morb Mortal Wkly Rep, 45, 1-65.

Beaufort A, Rudelle S, Gnanou-Besse N, Toquin M T, Kerouanton A, Bergis H, Salvat G and Cornu M (2007), 'Prevalence and growth of Listeria monocytogenes in naturally contaminated cold-smoked salmon', Lett Appl Microbiol, 44, 406-411.

Bhugaloo-Vial P, Dousset X, Metivier A, Sorokine O, Anglade P, Boyaval P and Marion D (1996), 'Purification and amino acid sequences of Piscicocins V1a and V1b, two class Ila bacteriocins secreted by Carnobacterium maltaromaticum V1 that display significantly different levels of specific inhibitory activity', Appl Environ Microbiol, 62, 4410-4416.

Brillet A, Pilet M F, Prévost H, Bouttefroy A and Leroi F (2004), 'Biodiversity of Listeria monocytogenes sensitivity to bacteriocin-producing Carnobacterium strains and application in sterile cold-smoked salmon', J Appl Bacteriol, 97, 1029-1037.

Brillet A, Pilet M F, Prévost H, Cardinal M and Leroi F (2005), 'Effect of inoculation of Carnobacterium divergens V41, a biopreservative strain against Listeria monocytogenes risk, 
on the microbiological, and sensory quality of cold-smoked salmon', Int J Food Microbiol, 104, 309-324.

Calo-Mata P, Arlindo S, Boehme K, de Miguel T, Pascoal A and Barros-Velazquez J (2008), 'Current applications and future trends of lactic acid bacteria and their bacteriocins for the biopreservation of aquatic food products', Food and Bioprocess Technology, 1, 43-63.

Cardinal M, Gunnlaugsdottir H, Bjoernevik M, Ouisse A, Vallet J L and Leroi F (2004), 'Sensory characteristics of cold-smoked atlantic salmon (Salmo salar) from European market and relationships with chemical, physical and microbiological measurements', Food Res Int, 37, 181-193.

Commission Regulation 1441/2007/EC of 5 December 2007 amending Regulation (EC) No 2073/2005 on microbiological criteria for foodstuffs. O J E U 322, 7.12.2007, 12-29.

Dalgaard $\mathrm{P}$ and Emborg $\mathrm{J}$ (2008), Histamine ang biogenic amines: formation and importance in seafood, in BORRESEN, T (Ed.) Improving seafood products for the consumer, Cambridge, Woodhead publishing limited.

Dalgaard P, Madsen H L, Samieian N and Emborg J (2006), 'Biogenic amine formation and microbial spoilage in chilled garfish (Belone belone belone) - effect of modified atmosphere packaging and previous frozen storage', J Appl Microbiol, 101, 80-95.

Dalgaard P, Mejlholm O, Christiansen T J and Huss H H (1997), 'Importance of Photobacterium phosphoreum in relation to spoilage of modified atmosphere-packed fish products', Lett Appl Microbiol, 24, 373-378.

Dalgaard P, Vancanneyt M, Euras Vilalta N, Swings J, Fruekilde P and Leisner J J (2003), 'Identification of lactic acid bacteria from spoilage associations of cooked and brined shrimps stored under modified atmosphere between $0^{\circ} \mathrm{C}$ and $25^{\circ} \mathrm{C}^{\prime}, \mathrm{J}$ Appl Microbiol, 94, 80-89.

Daniel P and Lorre S (2001) Novel lactic acid bacteria of the genus Lactococcus lactis and use thereof for preserving food products. Patent WO 2003/027268.

Dortu C and Thonart P (2009), 'Bacteriocins from lactic acid bacteria: interest for food products biopreservation', Biotechnol Agron Soc Environ, 13, 143-154.

Drider D, Fimland G, Héchard Y, Mc Mullen L M and Prévost H (2006), 'The continuing story of class Ila bacteriocins', Microbiol Mol Biol Rev, 70, 564-582.

Duffes F, Corre C, Leroi F, Dousset X and Boyaval P (1999), 'Inhibition of Listeria monocytogenes by in situ produced and semipurified bacteriocins of Carnobacterium spp. on vacuum-packed, refrigerated cold-smoked salmon', J Food Prot, 62, 1394-1403.

Fliss I, Desbiens M, Lacroix C, Tahiri I, Benech R-O and Kheadr E (2004), Bacterial strain and bacteriocin produced therefrom. US Patent App. 10/834,886, 2004.

EFSA (2007), 'Introduction of a Qualified Presumption of Safety (QPS) approach for assessment of selected microorganisms referred to EFSA. Opinion of the Scientific Committee (Question No EFSA-Q-2005-293)'. EFSA J, 587, 1-16.

EFSA (2008), 'The maintenance of the list of QPS microorganisms intentionally added to food or feed', EFSA J, 923, 1-48.

Einarsson $\mathrm{H}$ and Lauzon H L (1995), 'Biopreservation of brined shrimp (Pandalus borealis) by bacteriocins from lactic acid bacteria', Appl Environ Microbiol, 61, 669-676.

Eldar A, Ghittino C, Asanta L, Bozzetta E, Goria M, Prearo M and Bercovier H (1996), 'Enterococcus seriolicida is a junior synonym of Lactococcus garvieae, a causative agent of septicemia and meningoencephalitis in fish', Curr Microbiol, 32, 85-88.

Emborg J and Dalgaard P (2006), 'Formation of histamine and biogenic amines in coldsmoked tuna: An investigation of psychrotolerant bacteria from samples implicated in cases of histamine fish poisoning', J Food Prot, 69, 897-906.

Emborg J, Laursen B G, Rathjen T and Dalgaard P (2002), 'Microbial spoilage and formation of biogenic amines in fresh and thawed modified atmosphere-packed salmon (Salmo salar) at $2^{\circ} \mathrm{C}^{\prime}, \mathrm{J}$ Appl Microbiol, 92, 790-799.

Fall P A, Leroi F, Cardinal M, Chevalier F and Pilet M F (2010), 'Inhibition of Brochotrix thermosphacta and sensory improvement of tropical peeled cooked shrimp by Lactococcus piscium CNCM I-4O31', Lett Appl Microbiol, in press.

Feldhusen F (2000), 'The role of seafood in bacterial foodborne diseases', Methods Microbiol, 2, 1651-1660. 
Fletcher G C, Summers G, Corrigan V K, Johanson M R and Hedderley D (2004), 'Optimizing gas mixtures for modified atmosphere packaging of fresh king salmon (Oncorhynchus tshawytscha)', J Aquat Food Prod Technol, 13, 5-28.

Gancel F, Dzierszinski F and Tailliez R (1997), 'Identification and characterization of Lactobacillus species isolated from fillets of vacuum-packed smocked and salted herring (Clupea harengus)', J Appl Microbiol, 82, 722-728.

Garcia P, Martinez B, Obeso J M and Rodriguez A (2008), 'Bacteriophages and their application in food safety', Lett Appl Microbiol, 47, 479-85.

Gonzalez-Rodriguez M N, Sanz J J, Santos J A, Otero A and Garcia-Lopez M L (2002), 'Numbers and types of microorganisms in vacuum-packed cold-smoked freshwater fish at the retail level', Int J Food Microbiol, 77, 161-168.

Gram L and Huss H H (1996), 'Microbiological spoilage of fish and fish products', Int J Food Microbiol, 33, 121-137.

Gudmundsdöttir S, Gudbjörnsdottir B, Lauzon H, Einarsson H, Kristinsson K G and Kristjansson M (2005), 'Tracing Listeria monocytogenes isolates from cold smoked salmon and its processing environment in Iceland using pulsed-field gel electrophoresis', Int J Food Microbiol, 101, 41-51.

Guenther S, Huwyler D, Richard S and Loessner M J (2009), 'Virulent bacteriophage for efficient biocontrol of Listeria monocytogenes in ready-to-eat foods', Appl Environ Microbiol, 75, 93-100.

Hildebrandt G and Erol I (1988), 'Sensorische und mikrobiologische untersuchung an vakuumverpackten räucherlachs in scheiben (Sensory and microbiological analysis of vacuum packed sliced smoked salmon)', Arch Lebensmittelhyg, 39, 120-123.

Hu Y, Gall K, Ho A, Ivanek R, Grohn Y T and Wiedmann M (2006), 'Daily variability of Listeria contamination patterns in a cold-smoked salmon processing operation', J Food Prot, 69, 2123-2133.

Huber I, Spanggaard B, Appel K F, Rossen L, Nielsen T and Gram L (2004), 'Phylogenetic analysis and in situ identification of the intestinal microbial community of rainbow trout (Oncorhynchus mykiss, Walbaum)', J Appl Microbiol, 96, 117-132.

Huss H H, Jeppesen V F, Johansen C and Gram L (1995), 'Biopreservation of fish products A review of recent approaches and results', J Aquat Food Prod Technol, 4, 5-26.

Huss H H, Reilly A and Ben Embarek P K (2000), 'Prevention and control of hazards in seafood', Food Control, 11, 149-156.

Jaffrès $E$, Sohier D, Leroi F, Pilet M F, Prévost H, Joffraud J J and Dousset X (2008), 'Study of the bacterial ecosystem in tropical cooked and peeled shrimps using a polyphasic approach', Int J Food Microbiol, 131, 20-29.

Jöborn A, Dorsch M, Olsson J C, Westerdahl A and Kjelleberg S (1999), 'Carnobacterium inhibens sp. nov., isolated from the intestine of Atlantic salmon (Salmo salar)', Int J Syst Bacteriol, 49, 1891-1898.

Joffraud J J, Cardinal M, Cornet J, Chasles J S, Léon S, Gigout F and Leroi F (2006), 'Effect of bacterial interactions on the spoilage of cold-smoked salmon', Int J Food Microbiol, 112, 51-61.

Joffraud J J, Leroi F, Roy C and Berdagué J L (2001), 'Characterisation of volatile compounds produced by bacteria isolated from the spoilage flora of cold-smoked salmon', Int J Food Microbiol, 66, 175-184.

Jorgensen L V, Dalgaard P and Huss H H (2000), 'Multiple compound quality index for coldsmoked salmon (Salmo salar) developed by multivariate regression of biogenic amines and pH', J Agric Food Chem, 48, 2448-2453.

Jorgensen L V and Huss H H (1998), 'Prevalence and growth of Listeria monocytogenes in naturally contaminated seafood', Int J Food Microbiol, 42, 127-131.

Katla T, Moretro T, Aasen I M, Holck A, Axelsson L and Naterstad K (2001), 'Inhibition of Listeria monocytogenes in cold smoked salmon by addition of sakacin $\mathrm{P}$ and/or live Lactobacillus sakei cultures', Food Microbiol, 18, 431-439. 
Lalitha K V, Sonaji E R, Manju S, Jose L, Gopal T K S and Ravisankar C N (2005), 'Microbiological and biochemical changes in pearl spot (Etroplus suratensis Bloch) stored under modified atmospheres', J Appl Microbiol, 99, 1222-1228.

Laursen B G, Bay L, Cleenwerck I, Vancanneyt M, Swings J, Dalgaard P and Leisner J J (2005), 'Carnobacterium divergens and Carnobacterium maltaromaticum as spoilers or protective cultures in meat and seafood: phenotypic and genotypic characterisation', Syst Appl Microbiol, 28, 151-164.

Laursen B G, Leisner J J and Dalgaard P (2006), 'Carnobacterium species: Effect of metabolic activity and interaction with Brochothrix thermosphacta on sensory characteristcs of modified atmosphere packed shrimp', J Agric Food Chem, 54, 3604-3611.

Lee R J and Rangdale R E (2008), Bacterial pathogens in seafood, in BORRESEN, T (Ed.) Improving seafood products for the consumer, Cambridge, Woodhead Publishing Limited.

Lee W C, Sakai T, Lee M J, Hamakawa M, Lee S M and Lee I M (1996), 'An epidemiological study of food poisoning in Korea and Japan', Int J Food Microbiol, 29, 141-148.

Leisner J J (1992) Characterisation of lactic acid bacteria isolated from lightly preserved fish products and their ability to metabolise various carbohydrates and amino acids. PhD thesis. Technologycal Laboratory, Lyngby. Copenhagen, Denmark, The Royal Veterinary and Agricultural University.

Leisner J J, Laursen B G, Prevost H, Drider D and Dalgaard P (2007), 'Carnobacterium: positive and negative effects in the environment and in foods', FEMS Microbiol Rev, 31, 592613.

Leroi F, Arbey N, Joffraud J J and Chevalier F (1996), 'Effect of inoculation with lactic acid bacteria on extending the shelf-life of vacuum-packed cold-smoked salmon', Int J Food Sci Technol, 31, 497-504.

Leroi F, Joffraud J J and Chevalier F (2000), 'Effect of salt and smoke on the microbiological quality of cold smoked salmon during storage at $5^{\circ} \mathrm{C}$ as estimated by the factorial design method', J Food Prot, 63, 502-508.

Leroi F, Joffraud J J, Chevalier F and Cardinal M (1998), 'Study of the microbial ecology of cold smoked salmon during storage at $8^{\circ} \mathrm{C}^{\prime}$, Int $\mathrm{J}$ Food Microbiol, 39, 111-121.

Leroi F, Joffraud J J, Chevalier F and Cardinal M (2001), 'Research of quality indices for cold-smoked salmon using a stepwise multiple regression of microbiological counts and physico-chemical parameters', J Appl Microbiol, 578-587.

Liu J Y, Li A H, Ji C and Yang W M (2009), 'First description of a novel Weissella species as an opportunistic pathogen for rainbow trout Oncorhynchus mykiss (Walbaum) in China', Vet Microbiol, 136, 314-320.

Lyhs U, Björkroth J, Hyytiä E and Korkeala H (1998), 'The spoilage flora of vacuumpackaged, sodium nitrite or potassium nitrate treated, cold smoked rainbow trout stored at $4^{\circ} \mathrm{C}$ ou $8^{\circ} \mathrm{C}^{\prime}$, Int $\mathrm{J}$ Food Microbiol, 45, 135-142.

Lyhs U, Korkeala H, Vandamme P and Björkroth J (2001), 'Lactobacillus alimentarius: a specific spoilage organism in marinated herring', Int J Food Microbiol, 64, 355-360.

Mah J-H and Hwang H-J (2009), 'Inhibition of biogenic amine formation in a salted and fermented anchovy by Staphylococcus xylosus as a protective culture', Food Control, 20, 796-801.

Matamoros S, Leroi F, Cardinal M, Gigout F, Kasbi Chadli F, Cornet J, Prevost F and Pilet M F (2009a), ' Psychrotrophic lactic acid bacteria used to improve the safety and quality of vacuum-packaged cooked and peeled tropical shrimp and cold-smoked salmon', $J$ Food Prot, 72, 365-374.

Matamoros S, Pilet M F, Gigout F, Prévost H and Leroi F (2009b), 'Selection and evaluation of seafood-borne psychrotrophic lactic acid bacteria as inhibitors of pathogenic and spoilage bacteria', Food Microbiol, 26, 638-644.

Mejlholm O, Boknaes N and Dalgaard P (2005), 'Shelf life and safety aspects of chilled cooked and peeled shrimps (Pandalus borealis) in modified atmosphere packaging', J Appl Microbiol, 99, 66-76.

Métivier A, Pilet M F, Dousset X, Sorokine O, Anglade P, Zagorec M, Piard J C, Marion D, Cenatiempo $Y$ and Fremaux C (1998), 'Divercin V41, a new bacteriocin with two disulphide 
bonds produced by Carnobacterium divergens V41: primary structure and genomic organization', Microbiology, 144, 2837-2844.

Meyer H L (2005), 'La bioprotection élargit son périmètre', RIA, 659, 57-58.

Nakamura $\mathrm{H}$, Hatanaka M, Ochi K, Nagao M, Ogasawara J, Hase A, Kitase T, Haruki K and Nishikawa Y (2004), 'Listeria monocytogenes isolated from cold-smoked fish products in Osaka city, Japan', Int J Food Microbiol, 94, 323-328.

Nauth K R and Zheng Z (2006) Anti-listeria compositions for use in food products. Patent US 7001632.

Nilsson L (1999) Control of Listeria monocytogenes in cold-smoked salmon by biopreservation. Ph-D Thesis, Danish Institute for Fisheries Research and The Royal Veterinary and Agricultural University of Copenhagen, Denmark.

Nilsson L, Gram L and Huss H H (1999), 'Growth control of Listeria monocytogenes on coldsmoked salmon using a competitive lactic acid bacteria flora', J Food Prot, 62, 336-342.

Nilsson L, Huss H H and Gram L (1997), 'Inhibition of Listeria monocytogenes on coldsmoked salmon by nisin and carbon dioxide atmosphere', Int J Food Microbiol, 38, 217-227.

Nilsson L, Ng Y Y, Christiansen J N, Jorgensen B L, Grotinum D and Gram L (2004), 'The contribution of bacteriocin to inhibition of Listeria monocytogenes by Carnobacterium piscicola strains in cold-smoked salmon systems', J Appl Microbiol, 96, 133-143.

Paludan-Müller C, Dalgaard P, Huss H H and Gram L (1998), 'Evaluation of the role of Carnobacterium piscicola in spoilage of vacuum and modified atmosphere-packed-smoked salmon stored at $5^{\circ} \mathrm{C}^{\prime}$, Int $\mathrm{J}$ Food Microbiol, 39, 155-166.

Pinto A L, Fernandes M, Pinto C, Albano H, Castilho F, Teixeira P and Gibbs P A (2009), 'Characterization of anti-Listeria bacteriocins isolated from shellfish: Potential antimicrobials to control non-fermented seafood', Int J Food Microbiol, 129, 50-58.

Richard C, Brillet A, Pilet M F, Prévost H and Drider D (2003), 'Evidence on inhibition of Listeria monocytogenes by divercin V41 action', Lett Appl Microbiol, 36, 288-292.

Ringo E and Gatesoupe F J (1998), 'Lactic acid bacteria in fish: a review', Aquaculture, 160, 177-203.

Ringo E, Wesmajervi M S, Bendiksen H R, Berg A, Olsen R E, Johnsen T, Mikkelsen H, Seppola M, Strom E and Holzapfel W H (2001), 'Identification and characterization of carnobacteria isolated from fish intestine', Syst Appl Microbiol, 24, 183-191.

Rodgers S (2001), 'Preserving non-fermented refrigerated foods with microbial cultures: a review', Trends in Food Science and Technology, 12, 276-284.

Srionnual S, Yanagida F, Lin L H, Hsiao K N and Chen Y S (2007), 'Weissellicin 110, a newly discovered bacteriocin from Weissella cibaria 110, isolated from plaa-som, a fermented fish product from Thailand', Appl Environ Microbiol, 73, 2247-50.

Stiles M E, McMullen L and Smith D C (2005) Lactic acid bacteria for the treatment of food. Patent US Application 2005/0153033.

Stoffels G, Nissen-Meyer J, Gudmundsdottir A, Sletten K, Holo H and Nes I F (1992), 'Purification and characterization of a new bacteriocin isolated from a Carnobacterium sp', Appl Environ Microbiol, 58, 1417-22.

Stohr V, Joffraud J J, Cardinal M and Leroi F (2001), 'Spoilage potential and sensory profile associated with bacteria isolated from cold-smoked salmon', Food Res Int, 34, 797-806.

Sumner J and Ross T (2002), 'A semi-quantitative seafood safety risk assessment', Int J Food Microbiol, 77, 55-59.

Tahiri I, Desbiens M, Benech R, Kleadr E, Lacroix C, Thibault S, Ouellet D and Fliss I (2004), 'Purification, characterization and amino acid sequencing of divercin M35: a novel class Ila bacteriocin produced by Carnobacterium divergens', Int J Food Microbiol, 97, 123-136.

Tahiri I, Desbiens M, Kheadr E, Lacroix C and Fliss I (2009), 'Comparison of different application strategies of divergicin M35 for inactivation of Listeria monocytogenes in coldsmoked wild salmon'. Food Microbiol, 26, 783-93.

Tang Y W, Wang J X, Xu Z Y, Guo Y F, Qian W H and Xu J X (1991), 'A serologically confirmed, case-control study, of a large outbreak of hepatitis-A in China, associated with consumption of clams', Epidemiol Infect, 107, 651-657. 
Tomé E, Gibbs P A and Teixeira P C (2008), 'Growth control of Listeria innocua 2030c on vacuum-packaged cold-smoked salmon by lactic acid bacteria', Int J Food Microbiol, 121, 285-294.

Toranzo A E, Novoa B, Baya A M, Hetrick F M, Barja J L and Figueras A (1993), 'Histopathology of rainbow trout, Onchorhynchus mykiss (Walbaum), and striped bass, Morone saxatilis (Walbaum), experimentally infected with Carnobacterium piscicola', J Fish Dis, 16, 261-267.

Valdimarsson G, Einarsson H, Gudbjörnsdottir B and Magnusson H (1998), 'Microbiological quality of Icelandic cooked-peeled shrimp (Pandalus borealis)', Int J Food Microbiol, 45, 157161.

Veciana-Nogues M T, Marine.Font A and Vidal-Carou M C (1997), 'Biogenic Amines as Hygienic Quality Indicators of Tuna. Relationships with Microbial Counts, ATP-Related Compounds, Volatile Amines, and Organoleptic Changes', J Agric Food Chem, 45, 20362041.

Vescovo M, Scolari G and Zacconi C (2006), 'Inhibition of Listeria innocua growth by antimirobial-producing lactic acid cultures in vacuum-packed cold-smoked salmon', Food Microbiol, 23, 689-693.

Weiss A and Hammes W P (2006), 'Lactic acid bacteria as protective cultures against Listeria spp. on cold smoked salmon', Eur Food Res Technol, 222, 343-346.

Wittman R J and Flick G J (1995), 'Microbial contamination of shellfish: prevalence, risk to human health, and control strategies', Annu Rev Public Health, 16, 123-140.

Yamazaki K, Suzuki M, Kawai Y, Inoue N and Montville T J (2003), 'Inhibition of Listeria monocytogenes in cold-smoked salmon by Carnobacterium piscicola CS526 isolated from frozen surimi', J Food Prot, 66, 1420-5.

Yamazaki K, Suzuki M, Kawai Y, Inoue N and Montville T J (2005), 'Purification and characterization of a novel class Ila bacteriocin, piscicocin CS526, from surimi-associated Carnobacterium piscicola CS526', Appl Environ Microbiol, 71, 554-7.

Yang G, Bao B, Peatman E, Li H, Huang, L and Ren D (2007), 'Analysis of the composition of the bacterial community in puffer fish Takifugu obscurus', Aquaculture, 262, 183-191.

Yin L-J, Wu C-W and Jiang S-T (2007), 'Biopreservative effect of pediocin ACCEL on refrigerated seafood', Fish Sci, 73, 907-912.

Yongjin H, Wenshui $X$ and L. X (2007), 'Changes in biogenic amines in fermented silver carp sausages inoculated with mixed starter cultures', Food Chem, 104, 188-195. 
Tables

Table 1 : Risk categories for seafood products and associated microorganisms

\begin{tabular}{|c|c|c|}
\hline Risk & Seafood products & Agent \\
\hline \multirow[t]{5}{*}{ High } & Mollusc (fresh or frozen) & $\begin{array}{l}\text { Virus, bacteria, toxin } \\
\text { microalgae (heatstable) }\end{array}$ \\
\hline & Raw fish : Ceviche, Suchi etc. & Indigenous bacteria (Vibrio) \\
\hline & $\begin{array}{l}\text { Lightly preserved fish }(\mathrm{NaCl}<6 \% \\
\text { WP, pH }>5) \text { : carpaccio, cold- } \\
\text { smoked fish, marinated products, } \\
\text { gravads etc. }\end{array}$ & $\begin{array}{l}\text { Growth of indigenous bacteria } \\
\text { (Listeria monocytogenes, production } \\
\text { of toxin from Clostridium botulinum) }\end{array}$ \\
\hline & $\begin{array}{l}\text { Mildly heat processed: cooked } \\
\text { and peeled shrimp, salads, soup } \\
\text { etc. }\end{array}$ & $\begin{array}{l}\text { Recontamination with enteric } \\
\text { bacteria, growth of Listeria } \\
\text { monocytogenes, Vibrio }\end{array}$ \\
\hline & Scombroid fish & Histamine production \\
\hline \multirow[t]{3}{*}{ Low } & Cooked fish and crustacean & Ciguatera in tropical area \\
\hline & $\begin{array}{l}\text { Semi preserved fish }(\mathrm{NaCl}>6 \% \\
\text { WP, } \mathrm{pH}<5): \text { salted, dried, } \\
\text { marinated, hot smoked fish etc. }\end{array}$ & $\begin{array}{l}\text { Recontamination } \\
\text { bacteria }\end{array}$ \\
\hline & $\begin{array}{l}\text { Heat processed: sterilised, } \\
\text { canned etc. }\end{array}$ & Clostridium botulinum spore \\
\hline
\end{tabular}


Table 2: Applications of protective cultures for pathogenic bacteria control in seafood

\begin{tabular}{|c|c|c|c|c|c|c|}
\hline Products & Protective strains (inoculum level) & $\begin{array}{l}\text { Bacteriocinogenic } \mathrm{Y} / \mathrm{N} \\
\text { (bacteriocin name) }\end{array}$ & $\begin{array}{c}\text { Target } \\
\text { microorganisms } \\
\text { (inoculation level) }\end{array}$ & $\begin{array}{c}\text { Storage } \\
\text { conditions }\end{array}$ & Effect & Reference \\
\hline \multirow[t]{8}{*}{$\begin{array}{l}\text { Cold smoked } \\
\text { salmon }\end{array}$} & $\begin{array}{l}\text { Carnobacterium maltaromaticum A9b } \\
\left(10^{6} \mathrm{CFU} / \mathrm{g}\right) \\
\text { Carnobacterium maltaromaticum A10a } \\
\left(10^{6} \mathrm{CFU} / \mathrm{g}\right)\end{array}$ & $\begin{array}{l}\text { Y (carnobacteriocin B2) } \\
\mathrm{N}\end{array}$ & $\begin{array}{l}\text { L. monocytogenes } \\
\left(210^{2} \mathrm{CFU} / \mathrm{g}\right)\end{array}$ & $\begin{array}{l}\text { Vacuum } \\
\text { packed } 32 \mathrm{~d} \text { at } \\
5^{\circ} \mathrm{C}\end{array}$ & $\begin{array}{l}\text { Initial level till } 25 \mathrm{~d} \text { and decrease } \\
\text { below } 1 \mathrm{CFU} / \mathrm{g} \\
10^{3} \mathrm{CFU} / \mathrm{g} \text { maintained during } 31 \mathrm{~d}\end{array}$ & $\begin{array}{l}\text { Nilsson et al. } \\
\text { 1999, } 2004 \\
\text { Nilsson et al. } \\
1999\end{array}$ \\
\hline & $\begin{array}{l}\text { Carnobacterium divergens V41 } \\
\left(10^{5} \mathrm{CFU} / \mathrm{g}\right) \\
\text { Carnobacterium divergens V1 } \\
\left(10^{5} \mathrm{CFU} / \mathrm{g}\right) \\
\text { Carnobacterium divergens SF668 }\left(10^{5} \mathrm{CFU} / \mathrm{g}\right)\end{array}$ & $\begin{array}{l}\text { Y (divercin V41) } \\
\text { Y (piscicocin V1a and } \\
\text { V1b) } \\
\text { Y (unknown) }\end{array}$ & $\begin{array}{l}\text { L. monocytogenes } \\
(20 \text { CFU/g) }\end{array}$ & $\begin{array}{l}\text { Vacuum } \\
\text { packed } 9 \mathrm{~d} \text { at } \\
4^{\circ} \mathrm{C} \text { and } 19 \mathrm{~d} \\
\text { at } 8^{\circ} \mathrm{C}\end{array}$ & $\begin{array}{l}20 \text { CFU/g maintained during } 28 \mathrm{~d} \\
<10^{2} \text { CFU/g maintained during } 28 \mathrm{~d} \\
\text { Growth limitation of } 1 \text { to } 3 \mathrm{log} \\
\text { CFU/g at the end of storage period }\end{array}$ & $\begin{array}{l}\text { Brillet et al. } \\
2004\end{array}$ \\
\hline & $\begin{array}{l}\text { Carnobacterium maltaromaticum CS526 } \\
\left(10^{4} \text { or } 10^{6} \mathrm{CFU} / \mathrm{g}\right) \\
\text { Carnobacterium maltaromaticum JCM5348 } \\
\left(10^{4} \text { or } 10^{6} \mathrm{CFU} / \mathrm{g}\right)\end{array}$ & $\begin{array}{l}\text { Y (piscicocin CS526) } \\
\mathrm{N}\end{array}$ & $\begin{array}{l}\text { L. monocytogenes } \\
\left(10^{3} \mathrm{CFU} / \mathrm{g}\right)\end{array}$ & $\begin{array}{l}\text { Vacuum } \\
\text { packed } 21 \mathrm{~d} \text { at } \\
4^{\circ} \mathrm{C}\end{array}$ & $\begin{array}{l}\text { Decrease till } 10^{2} \mathrm{CFU} / \mathrm{g} \text { after } 12 \mathrm{~d} \\
\text { maintained during } 24 \mathrm{~d} \\
\text { Initial level maintained during } 24 \mathrm{~d}\end{array}$ & $\begin{array}{l}\text { Yamazaki et } \\
\text { al. } 2003\end{array}$ \\
\hline & Carnobacterium divergens M35 (10 $\mathrm{CFU} / \mathrm{g})$ & Y (divergicin M35) & $\begin{array}{l}\text { L. monocytogenes } \\
\left(10^{2} \text { CFU/g) }\right.\end{array}$ & $\begin{array}{l}\text { Vacuum } \\
\text { packed } 21 \mathrm{~d} \text { at } \\
4^{\circ} \mathrm{C}\end{array}$ & $\begin{array}{l}\text { Growth limitation of } 3 \log \text { CFU/g } \\
\text { after } 21 \mathrm{~d}\end{array}$ & $\begin{array}{l}\text { Tahiri et al. } \\
2009\end{array}$ \\
\hline & $\begin{array}{l}\text { Lactobacillus sakei Lb790 } \\
\left(10^{3} \text { CFU/g) }\right. \\
\text { Lactobacillus sakei Lb790 }\left(10^{3} \text { CFU/g }\right)+ \\
\text { sakacine P }(1,1 \mu \mathrm{g} / \mathrm{g})\end{array}$ & $\mathrm{Y}($ sakacin $\mathrm{P})$ & $\begin{array}{l}\text { L. monocytogenes } \\
\left(10^{3} \text { CFU/g) }\right.\end{array}$ & $\begin{array}{l}\text { Vacuum } \\
\text { packed } 28 \mathrm{~d} \text { at } \\
10^{\circ} \mathrm{C}\end{array}$ & $\begin{array}{l}\text { Initial level maintained during } 28 \mathrm{~d} \\
\text { Decrease till } 10^{2} \mathrm{CFU} / \mathrm{g} \text { in } 28 \mathrm{~d}\end{array}$ & $\begin{array}{l}\text { Katla et al. } \\
2001\end{array}$ \\
\hline & $\begin{array}{l}\text { Lactobacillus sakei } 5754 \\
\left(10^{7} \mathrm{UFC} / \mathrm{g}\right)\end{array}$ & Y (unknown) & $\begin{array}{l}\text { L. inocua } \\
\left(10^{4} \mathrm{CFU} / \mathrm{g}\right)\end{array}$ & $\begin{array}{l}\text { Vacuum } \\
\text { packed } 14 \mathrm{~d} \text { at } \\
4^{\circ} \mathrm{C}\end{array}$ & $\begin{array}{l}\text { Growth limitation of } 4 \text { log CFU/g } \\
\text { after } 14 \mathrm{~d}\end{array}$ & $\begin{array}{l}\text { Weiss and } \\
\text { Hammes } \\
2006\end{array}$ \\
\hline & $\begin{array}{l}\text { Lactobacillus casei } \mathrm{T} 3 \text { and Lactobacillus } \\
\text { plantarum } \mathrm{Pe} 2 \\
\left(10^{6} \mathrm{CFU} / \mathrm{g}\right)\end{array}$ & Y (unknown) & $\begin{array}{l}\text { L. innocua } \\
\left(10^{4} \mathrm{CFU} / \mathrm{g}\right)\end{array}$ & $\begin{array}{l}\text { Vacuum } \\
\text { packed } 30 \mathrm{~d} \text { at } \\
4^{\circ} \mathrm{C}\end{array}$ & $\begin{array}{l}\text { Growth limitation of 1,5 log CFU/g } \\
\text { after } 30 \mathrm{~d}\end{array}$ & $\begin{array}{l}\text { Vescovo et } \\
\text { al. } 2006\end{array}$ \\
\hline & $\begin{array}{l}\text { Enterococcus faecium ET05 } \\
\text { (nd) }\end{array}$ & Y (unknown) & $\begin{array}{l}\text { L. innocua } \\
\left(10^{4} \mathrm{CFU} / \mathrm{g}\right)\end{array}$ & $\begin{array}{l}\text { Vacuum } \\
\text { packed } 21 \mathrm{~d} \text { at } \\
5^{\circ} \mathrm{C}\end{array}$ & $\begin{array}{l}\text { Growth limitation of 2,5 log CFU/g } \\
\text { after } 21 \text { days }\end{array}$ & $\begin{array}{l}\text { Tomé et al. } \\
2008\end{array}$ \\
\hline Cooked shrimp & $\begin{array}{l}\text { Lactococcus piscium EU2241 } \\
\left(10^{5} \mathrm{UFC} / \mathrm{g}\right) \\
\text { Leuconostoc gelidum EU2247 } \\
\left(10^{5} \mathrm{UFC} / \mathrm{g}\right)\end{array}$ & Y (unknown) & $\begin{array}{l}\text { L. monocytogenes }\left(10^{3}\right. \\
\text { CFU/g) } \\
\text { S. aureus }\left(10^{3} \mathrm{CFU} / \mathrm{g}\right)\end{array}$ & $\begin{array}{l}\text { Vacuum } \\
\text { packed } 28 \mathrm{~d} \text { at } \\
8^{\circ} \mathrm{C} \text {, then } 7 \mathrm{~d} \\
\text { at } 20^{\circ} \mathrm{C}\end{array}$ & $\begin{array}{l}\text { Growth limitation of } 2 \text { log CFU/g } \\
\text { after } 7 \text { days and during the storage } \\
\text { period } \\
\text { Growth limitation of } 1,5 \log \text { CFU/g } \\
\text { after } 21 \text { days }\end{array}$ & $\begin{array}{l}\text { Matamoros } \\
\text { et al. } 2009\end{array}$ \\
\hline
\end{tabular}


Table 3: Bacteriocins from lactic acid bacteria isolated from seafood

\begin{tabular}{|c|c|c|c|c|}
\hline Bacteriocin name & Producing strain & Strain origin & Synonyms & Reference \\
\hline Piscicocin V1a & C. maltaromaticum V1 & Fish viscera & $\begin{array}{l}\text { Piscicolin } 126 \text { (Leisner et } \\
\text { al. 2007) }\end{array}$ & Bhugaloo-Vial et al., 1996 \\
\hline Piscicocin V1b & C. maltaromaticum V1 & Fish viscera & $\begin{array}{l}\text { Carnobacteriocin BM1 } \\
\text { (Leisner et al. 2007) }\end{array}$ & Bhugaloo-Vial et al., 1996 \\
\hline Divercin V41 & C. divergens V41 & Fish viscera & & Metivier et al., 1997 \\
\hline Weissellicin 110 & Weissella cibaria 110 & $\begin{array}{l}\text { Plaa-som, fermented fish } \\
\text { product }\end{array}$ & & Srionnual et al. 2007 \\
\hline Bac ALP7 & Enterococcus faecium ALP7 & Shellfish & Enterocin B & Pinto et al 2009 \\
\hline Bac ALP57 & $\begin{array}{l}\text { Pediococcus pentosaceus } \\
\text { ALP57 }\end{array}$ & Shellfish & Pediocin PA-1 & Pinto et al. 2009 \\
\hline
\end{tabular}

